ORIGINAL SCIENTIFIC PAPER

159.922.6.075-057.875(497.11)"2007/2013"

615.851-057.875(497.11)"2007/2013"

DOI:10.5937/ZRFFP45-8663

\author{
DUŠAN J. RANĐELOVIĆ ${ }^{1}$ \\ UNIVERSITY OF PRIŠTINA WITH TEMPORARY HEAD-OFFICE \\ In Kosovska Mitrovica, FacULTY of Philosophy \\ DePaRTMENT OF PSychology \\ Milica Z. Mitrović \\ UNIVERSITY OF Niš, FACULTY OF PHILOSOPHY \\ DEPARTMENT OF PSYCHOLOGY \\ DUŠAN LJ. TODOROVIĆ \\ UNIVERSITY OF Nis, FACULTY OF PHILOSOPHY \\ DEPARTMENT OF PSYCHOLOGY
}

\title{
PSYCHOLOGICAL COUNCELING CENTER FOR STUDENTS - NEED, DESIRE, NECESSITY ${ }^{2}$
}

\begin{abstract}
The period of studying is a time of actualization of the capacities of the individual in almost every aspect of life. The students face changes related to the stage of development they are going through, and to which new requests of adaptation are added during professional qualification. The increased rate of psychological problems shows a necessity for existence of student services that provide psychological help. The research results point out the positive effect of counseling and the importance of university counseling services for the students, the effect on their academic success, subjective welfare and their remaining at the faculty. The pilot-project „Psychological Counseling Center for Students” at the University of Nis is one of the largest and most permanent projects of this kind among universities of the region. The services of the counseling are completely free, and they are realized through three sectors: Counseling, Education and the Research Sector. Work reports of The Counseling service show that there is
\end{abstract}

\footnotetext{
alkadule9@yahoo.com

2 The paper presents in part the results of research conducted under the Project no. III 47023, Kosovo and Metohija between national identity and European integration, which is funded by the Ministry of Education, Science and Technological Development of the Republic of Serbia.

This paper was submitted on 4 July 2015 and accepted for publication at the meeting of the Editorial Board held on 8 October 2015.
} 
a need for this kind of psychological services and that the students are interested in attending seminars and debates where different aspects of mental health would be considered. The institutionalization of the above mentioned project, with the possible expansion of the network of psychological counseling services of this type in the region would give greater effects and contribute to the more comprehensive work concerning protection and improvement of the mental health of the students not only in Serbia, but also in surrounding countries.

KEY WORDS: students, psychological counseling center, prevention.

INTRODUCTION

Starting a faculty and studying is the time of actualization of one's capacities in almost every aspect of life. A significant feature of this period is the transition from adolescence to adulthood. Arnett (Arnett, 2000) uses the term "formation of maturity" for defining this period, because young people tend to perceive themselves sometimes as adolescents and sometimes as adults, which is a consequence of the process of establishing their own identity. The features of this period make it critical. As all young people, students are faced with psychological and psychosocial changes related to the developmental period they go through, accompanied by the difficulties and new adaptive demands on the studies, during the vocational training (Al-Qaisy, 2011). Thus, student life can be stressful for a young person. Some of identified stressors are too many tasks and obligations, competition, failures, the lack of money (Fairbrother \& Warn, 2003).

In discussing stress in young people, it is inevitable to also consider broader social community. The life of young people is also determined by political, economical and cultural context of the society they belong to. Perspectives, opportunities, support, incentives are the factors of development and progress of young people. The period of significant social changes that our society is going through brings with it large and rapid changes in the value system, where the old value system is rejected, while the new system is not yet established ${ }^{4}$. The social crisis leads to constraints and frustration, uncertainty and insecurity which especially affect young people. Such circumstances make them more vulnerable to the impacts of stressors associated with the student life. Authors Dimitrijevic and Randjelovic present the results of empirical study 
of mental health, conducted on a stratified sample of students $(\mathrm{N}=988)$ of the University of Nis and University of Pristina Dimitrijević \& Ranđelović, 2012). The results indicate that the students are very susceptible to stress, and that they have statistically significant higher values of primary aggression compared to the average values in the population. In the conclusion, the authors state the opinion that it is necessary to start a number of preventive activities with the aim to preserve and improve the mental health of young people. One form of preventive activities could be implemented through the Psychological Counseling Center for Students.

The importance of the social circumstances in which an individual develops is evidenced by a research conducted in 2006 on the students of European countries. This research compared the students from Western and Central-Eastern European countries (Bulgaria, Poland, Romania, Hungary and Slovakia) among other criteria, according to satisfaction with life and severity of depressive symptoms. The results indicate that students from CentralEastern Countries show higher level of depression, that depression is more common among these students and that they, in less extent, describe their lives as satisfactory (Wardle \& alii, 2004).

Exposure to stress carries certain consequences. The majority of students manage to adapt to the new life conditions and to deal with stressful situations in an appropriate way. However, a number of young people who need help is not negligible. A research conducted by Furr and his associates (Furr, Westefeld, McConnell, Jenkins, 2001) on the sample of 1455 students shows that students who suffer from depression symptoms in the period after starting a faculty, as a reason of their depressive mood usually state the problems with the academic achievement, loneliness, financial problems and problems in primary relationships.

Results of comparison of past and present generations of students indicate that the present generations are under greater stress (Ergene, Yildirim, 2004; Yildirim, 2006). Researches also show a higher rate of psychological disorders, especially depression and anxiety, among the students throughout the world (Adewuya, Ola, Olutayo, Mapayi, Oginni, 2006; Nerdrum, Rustøen, Rønnestad, 2006; Ovuga, Boardman, Wasserman, 2006).

Examining the correlation of the depressive mood and anxiety with self efficiency in the young, it is established that there is a negative correlation between aforementioned variables (Ghaderi and Salehi, 2011; Tahmassian and Moghadam, 2011). Al-Qaisy 
(2011) reports on the negative correlation between depression and academic achievement. The above mentioned data indicate the necessity of the activities on preserving the mental health of students and the need to provide the psychological support to those young people who need such help.

The results of the study conducted on the sample of students from Niš University show a significant correlation of subjective well-being and individual strategies of coping with stressful situations (Mitrović, Hadži Pesić \& Mitić, 2013). The authors of the aformentioned study draw attention to the necessity to work with young people on developing and fostering constructive ways to deal with stress, which may contribute to subjective well-being, which is one of the main determinants of mental health.

When it comes to the type of disorder, the results of the research conducted on the sample of American students indicate that the highest percentage of students shows the signs of depression (13.8\%), followed by panic or general anxiety disorder $(4.2 \%)$, while $2.5 \%$ are reported to have suicidal thoughts in the last four weeks (Eisenberg et al., 2007). Over the last five years, the following percentage of directors of university counseling centers have noticed an increase in the following problem: $78 \%$ of the crises that require immediate intervention, $77 \%$ of the questions and issues related to the psychiatric medications, $62 \%$ of learning disorders, $49 \%$ of drug abuse, $42 \%$ of self-mutilation and suffer (e.g. self-mutilation in order to reduce anxiety), $42 \%$ of alcohol, $30 \%$ of problems related to prior sexual abuse, $25 \%$ of questions and issues concerning career planning, $24 \%$ of eating disorders, $23 \%$ of concern related to sexual harassment in a campus (Gallagher, 2011). The results of the study conducted on a sample of students from Serbia show that there are elevations in certain scales that measure expression of various psychopathological symptoms (Zubić et al., 2012), and that differences in the intensity of some psychopathological symptoms are greater among a group of students from different faculties than within a group of students of the same faculty. 


\section{INTERNATIONAL EXPERIENCE IN THE WORK OF PRESERVATION OF MENTAL HEALTH OF STUDENTS}

The increasing rate of psychological problems and their consequences indicate that the student centers for providing psychological assistance have to exist. Examining the role of the counseling centers for students and the search for the best model started back in thirties and forties of the previous century (Hodges, 2001). From then to now there have been numerous changes in the organization and the method of providing psychological assistance, and in the needs and problems of the students, too. The initial purpose of student counseling centers was to help the students in the professional orientation, i.e. in aligning skills with professional interests. However, psychologist-counselors were soon to expand their focus beyond professional orientation. An increasing number of clients experienced problems in interpersonal relationships, so there was a growing need for the individual counseling. It set new requirements for the psychologists employed in the counseling centers regarding professional training and development and caused new manners of working that involved field work, prevention programs and counseling. With raising awareness of the importance of mental health and changing students' attitudes and beliefs about mental health, the number of students seeking psychological help increased. The group therapy was also introduced. The psychologists started cooperation with the organizations and institutions outside the University, in order to meet the needs of their clients. Today, student counseling centers include the following activities: career counseling, individual and group therapy, prevention programs, consultations, and also training and supervising the future psychologist-counselors (Sokol, 2009).

Examining the structure of the group of students using the services of the counseling center with respect to gender and the year of studies has shown that more young women than young men seek help and that freshmen and senior students are more common users of the counseling services (Benton et al., 2003; Dogan, 2012).

Obtaining help may have a positive influence on academic achievement, subjective well-being and retention at university. A 
research conducted by University of Idaho Student Counseling Center (Kitzrow, 2003) shows that $77 \%$ of the students, the counseling services users, reported that counseling had contributed to their retention at university and that their academic achievement would have been lower without counseling. $90 \%$ percent of the respondents stated that the counseling had helped them in achieving their goals at the University, as well as in reducing the stress that had affected their work. Turner and Berry (Turner and Berry, 2000 ) based on their six-year research report that $43.8 \%$ of clients state that counseling helped them in making the decision to continue studies. Moreover, the counseling services users included in this research show $11.4 \%$ higher rate of retention at university compared to general student population. The results of the research conducted by Wilson, Maison and Jiving (Wilson et al., 1997) suggest the positive correlation between the number of sessions and the rate of retention. The non-dropout rate for $14 \%$ higher for those students who visited the counseling center compared to the students who did not obtain this kind of help. Portter (Portter, 2011) finds the similar results in his research. The freshmen who have been the users of the individual counseling service within the counseling center show $7.6 \%$ higher rate of retention at University compared to all freshmen. Comparing the adaptation level of the students before and after counseling DeStefano, Melot and Petersen (DeStefano et al., 2001) get the results that show a significant increase on the scales measuring personal, social and academic adaptation.

The results of all above mentioned studies indicate the positive effects of counseling services and the importance of university counseling centers for student population. Early detection and work on the problem that a young person has is not only important for his/her academic achievement, but also for the prevention of potential more serious and larger scale problem. We can characterize the activities on founding and developing the psychological counseling centers for students as the activities for the benefit of young people. Unfortunately, in our country this practice is still at the beginning of its development and affirmation. The investment in the youth is the investment in the future of a society. In this process, mental health preservation has also a significant role. The psychological counseling centers with the manner of working customized to student population could represent an institution of the first choice and first aid to students. This need has been identi- 
fied in many countries around the world, where today psychological counseling centers for students offer various kinds of assistance to their users, and we could say that it is the help provided "in the right place at the right time".

Although the results of the work of psychological counseling centers for students at the prestigious European universities have shown the need for the existence for such a service at a university, at the universities in the region (Croatia, Bosnia, Montenegro, Bulgaria, Albania, Macedonia) as well as at the universities in Serbia, the importance of establishing this type of student service seem not to be recognized.

So far, various pilot projects of Psychological counseling centers for students have been started, mainly at individual faculties (e.g. Faculty of Philosophy, Univerzity of Belgrade, Faculty of Philosophy, Univerzity of Novi Sad), but, up to now, there have not been institutional forms of primary prevention in the field of mental health for this population.

The pilot project "Psychological counseling center for students" (http://www.savetni.org/o_nama.html) at Niš University is one of the largest and longest running projects of this type at universities in Serbia. This project is the only university counseling center in Serbia and it aims to strengthen the individual capacities of young people and to improve their social skills, to adopt problem solving skills, to channel anxiety and aggressiveness, as well as to raise the awareness of university students and high schools students and entire society on mental health prevention issues. The project has been active since 2007, and the leaders of the project are the Student Association of Niš University and the Association of Psychology PsihoN. In the previous years, the project has been supported by the Ministry of Education and Science of the Republic of Serbia and the Rectorate of Niš University. The services of the counseling center are completely free, and they are realized through three departments: Counseling, Education and Research Department. In addition to the direct counseling, implemented by trained psychotherapists (cognitive behavioral, psychoanalytic, and Gestalt orientation), SOS-teleapel service (which offers counseling services over the phone to students), internet counseling (students get the answers via e-mail to questions about their psychological problems/dilemmas), The Counseling Center offers students numerous seminars, round tables, panel discussions and similar activities on various topics related to the youth mental 
health prevention (depression, anxiety, learning disorders, eating disorders, communicational problems, emotional problems, etc.). Moreover, the Counseling Center organizes continuous empirical assessment of the different aspects of the mental health of the students (aggression, susceptibility to stress, self-esteem, life satisfaction, etc.) and their needs, too. In the Counseling Center, apart from eight therapists, there are 25 volunteers - psychologists and senior psychology students. The previous reports on the activities of the Counseling Center show that students are mostly satisfied with the services provided by the Counseling Center, that there is a need for this type of psychological services at the University and that there is the great interest of students to attend seminars and panel discussions to discuss various aspects of mental health.

\section{METHOD}

The paper presents quantitative results of the activities of the Psychological Counseling Center for Students in the period from 2007. to 2013. Most of these results have been presented in the form of announcements at the scientific meetings in the country and abroad. The results are compared across three parameters:

I) The results of the most significant empirical studies of mental health of students in that period; II) Descriptive data on the number of the clients who used the services of the Psychological Counseling Center for Students; III) The review of the most significant psychological problems faced by the users of the services of the Psychological Counseling Center for Students.

I) THE RESULTS OF THE MOST SIGNIFICANT EMPIRICAL STUDIES OF MENTAL HEALTH OF STUDENTS IN THE PERIOD FROM 2007. TO 2013.

During the period of operation of the Psychological Counseling Center for Students from 2007. to present, the counseling center has conducted a few empirical studies that have measured the needs of the students of Niš University to use the services of the Psychological Counseling Center, both from a subjective point of 
view (students' attitudes whether such an University instance is necessary to exist, and whether they are willing to use its services), and from objective point of view (the results of some tests that examine the different aspects of the young people's mental health: aggression, anxiety, stress susceptibility, susceptibility to pathological appearance of the symptoms of depression, phobia, somatization, and other). Studies also aimed at continuous monitoring of the mental health of the students of Niš University. For the sake of efficiency and clarity, here we provide the results of three, in our opinion, most significant studies (implemented during the school years 2007./08.; 2009./10.; 2012./13.).

\section{A) THE STUDY IMPLEMENTED IN THE SCHOOL YEAR 2007./2008.}

The main research objectives of this study were:

- To examine whether the students of Niš University are informed about the Psychological Counseling Center for Students and what are their attitudes towards is;

- To determine the objective indexes of the need for establishing the Psychological Counseling Center for the students, which are in the study represented through an intensity of certain so called "clinical scales" measured by MMPI.

The sample included 508 students from various faculties of Niš University. The technique used in obtaining the sample was stratified proportional sampling (the percentage of students from each faculty in the sample was equal to the percentage of students from individual faculties in total students population at Niš University). From the instruments, in addition to MMPI-202 (Biro, 2001), a questionnaire for the self-report of psychological distress was created for the purposes of the research.

The results show that only $16.3 \%$ of the interviewed students knows that in the city there is a free psychological counseling center which primarily deals with current issues of the students population, while even $83.7 \%$ of them have never heard that a counseling center for students exist.

Although $64 \%$ of respondents said that they at least once felt the need to talk to a psychologist or psychiatrist, still, even $87 \%$ of interviewed students had never sought their help or advice. The reason for that may lie in a predominantly negative attitude towards psychiatrists $(60 \%)$, and mostly neutral attitude towards 
psychologists (46\%). However, one of the reasons may lie in stereotypes and stigma that are still present in our society to the very act of contacting a specialist (a psychologist or a psychiatrist) in order to get psychological help.

Perhaps the most interesting finding of this part of the study is that even $85.6 \%$ of the respondents believe that the existence of the counseling center is necessary of even vital.

The willingness of the students to use the services of the free psychological counseling center was also investigated. $22.8 \%$ would be willing to contact and use the services of sos-counseling over the phone, while $33.7 \%$ of the interviewed students would be ready to use the service of the internet counseling via e-mail. From $20.4 \%$ of respondents who would be willing to apply for the services of the direct counseling and an interview with a psychologist, $17.1 \%$ of the interviewed students would be interested in individual counseling sessions, while $1.6 \%$ would be interested in counseling sessions in a group, and $1.4 \%$ in both type of counseling. As for the objective indicators of the need for the use of the services of the psychological counseling center, they have been compared through the scores on the certain clinical scales of MMPI.

As the part of the research, students of various faculties have been given the MMPI-202, too. The analysis of the obtained results, that is, the obtained profiles on the MMPI shows that the profiles of the interviewed students of almost all faculties are similar and that values on individual scales, both on the control and clinical, are in the range of $\mathrm{T}$ score 30 to 65 , i.e. within average limits. The obtained values of the control scales (L, F and $\mathrm{K}$ ) indicate the validity of the obtained profiles. The profile that differs from the majority is the profile of the students of the Law Faculty. Namely, the most of clinical scales exceed $\mathrm{T}$ score $\mathrm{P}$, while the following scales are especially emphasized: Paranoia $(\mathrm{Pa})$ and Schizophrenia (Sc), and also the scale of critical items ( $\mathrm{Ci}$ ). Such a profile could indicate the existence of more serious pathological manifestations, which is also confirmed by the obtained profile on the control scales in the shape of the inverted $\mathrm{V}$ (with the increase on the control scale F). However, one should bear in mind that this was a student population that was tested in groups, so the access to test material in such circumstances could compromised the obtained results. When conducting a group examination, the examiner was not able to observe the way the respondents accessed the test material, so it is evident that most respondents did not read the 
questions carefully and that after some time, they started answering the questions randomly. This assumption is confirmed by the increase on the control scale $\mathrm{F}$, and this way of work questions the obtained profile on the clinical scales. However, if we still try, with certain limits, to perceive the obtained results, we could say that some of the characteristics of the students of Law Faculty are caution, suspicion, distrust, rigidity, a specific cognitive style that are somewhat desirable traits for the success in the future occupation of these young people.

\section{B) THE STUDY IMPLEMENTED IN THE SCHOOL YEAR 2009/2010}

During the school year 2009/10, within the regular activities of the Counseling Center for Students, an empirical research was conducted on the sample of 279 students from four different faculties of Niš University (both the students of the sciences and engineering, and the students of humanities were included), with the aim to examine to what extent the students estimate to have the problems in the certain areas of daily living, such as 1) problems with learning and intellectual functioning, 2) problems in emotional relationships and 3) problems in establishing communication with other people or in social relations. The sample was a quota, from the Faculty of Electronic Engineering, Medical Faculty, the Faculty of Sciences and Mathematics and the Faculty of Philosophy of Niš University. The equal number of students was selected from each faculty and from each year of study. The sample was balanced by age and gender, and the age of the respondents varied from 19 to 27.

It proved that $7.5 \%$ of the interviewed students very frequently have problems in learning and intellectual functioning, $33.3 \%$ of the respondents have these problems occasionally, $37.5 \%$ of the respondents very rarely, while $15.4 \%$ of the respondents estimate not to have these problems.

$8.6 \%$ of the respondents have problems in emotional relations very frequently, while $38.4 \%$ of the interviewed students have them occasionally, and $35.1 \%$ of the respondents rarely. $11.8 \%$ of the respondents do not have these problems.

As for the frequency of problems in communication and social relations, 3.6\% of the interviewed students have them very frequently, $17.2 \%$ of the respondents estimate to have these problems occasionally, $40.9 \%$ of the respondents rarely experience 
problems in this sphere, and $30.8 \%$ of the interviewed students consider not to have these problems.

\section{C) THE STUDY IMPLEMENTED IN THE SCHOOL YEAR 2012/2013}

The survey conducted during the school year 2009./10. was thematically closely related to the research from 2007./08., while now, the study primarily focused on the objective (primary aggression and stress) and subjective (the attitudes of students) indicators of the students' needs for using the services of the Psychological Counseling Center. A part of these results is presented by the authors Dimitrijević and Randjelović (Dimitrijević and Ranđelović, 2012). The sample consisted of 988 students studying at the universities in the south of Serbia (Niš and Kosovska Mitrovica). The authors used subtest SIGMA of the test KON6, Bensaba's general test of stress, and the questionnaire for the assessment of the students' needs for using the services of the psychological counseling center. From the data processing techniques, they used descriptive statistics, $t$-test for the significance of the differences and ANOVA.

The result indicates that the students have statistically significant higher level of the prominence of the primary aggression compared to average values. The majority of students (81.2\%) think that the psychological counseling for students should exist, and that they would probably use ( $60.1 \%$ of the total sample size) the services provided by this free students service. Despite the fact that $62.4 \%$ of students have at least once felt the need to talk about their problems to a psychologist, and that there is the willingness to use the services of the free psychological counseling center, so far, the insufficient number of students have actually reported for help. The students who said that they have never felt the need to talk about their problems to a psychologist have statistically significant higher level of primary aggressiveness and are more susceptible to stress than those who have felt the need, and who have indicated their willingness to use the services of the psychological counseling center. Dimitrijević and Ranđelović (Dimitrijević and Ranđelović, 2012) emphasize that the experience of the Psychological Counseling Center in Niš shows an increase in the number of students who decide to report to a psychologist.

Very interesting data are obtained by the comparative analysis of the results of the researches from (2007/08.) and (2009/10.). Namely, it is checked to which institutions would students report 
in the event of socio-psychological problems. The majority of students $(29.3 \%)$ think that if they had a psychological problem, they should report to an official medical institution (like the health centers, the Institute of Mental Health), followed by private psychological practice (24.2\%), the Psychological Counseling Center for Students (22.4\%) and the students' polyclinic (16.9\%). Two years later, the situation is that the most of the interviewed students would report exactly to the Psychological Counseling Center for Students (29\%), followed by private psychological practice (27.2\%), official medical institutions (like the health centers and the Institute for Mental Health) (21.1\%) and the students' polyclinic (12.9\%).

II) DESCRIPTIVE DATA ON THE NUMBER OF THE CLIENTS WHO USED THE SERVICES OF THE PSYCHOLOGICAL COUNSELING CENTER FOR STUDENTS.

According to the data available on the official site of the Psychological Counseling Center for Students (http://www.savetni.org/ o_nama.html), the number of students who reported to the Psychological Counseling Center for Students for using the different services from 2007. to 2013. is shown in Figures 1, 2 and 3.

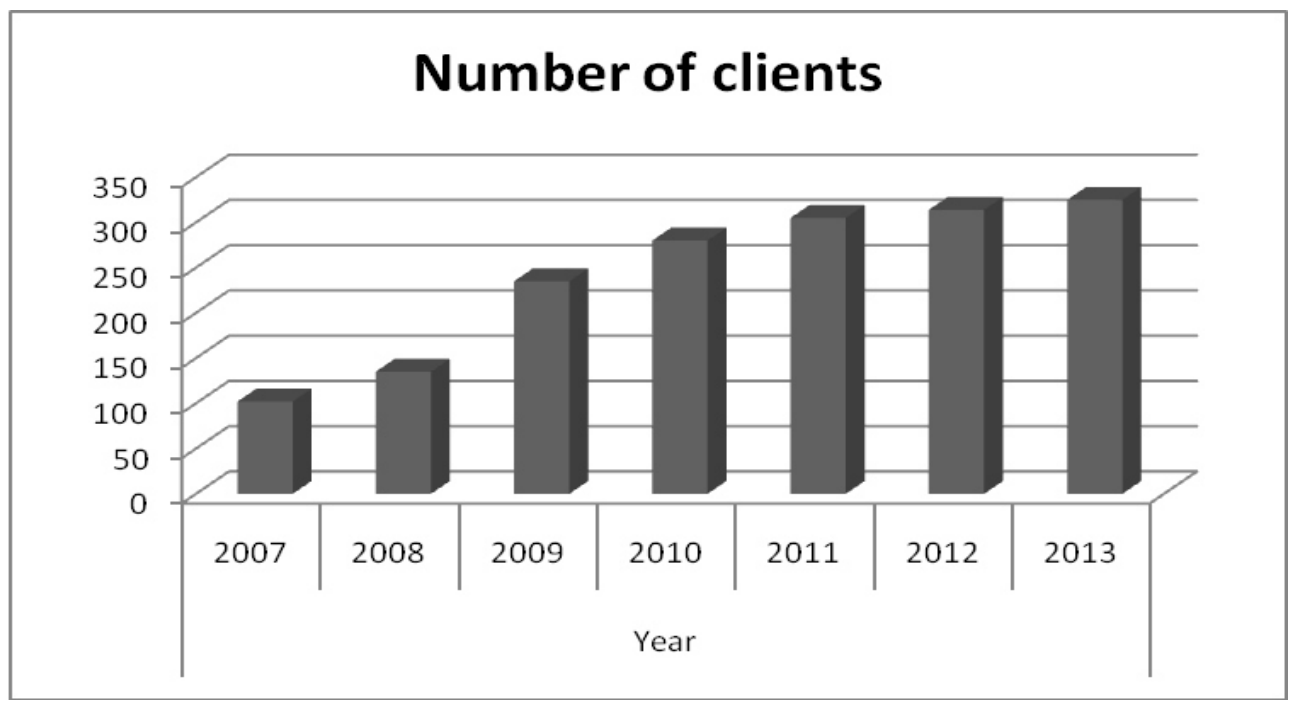

СЛИКA FIG. 1. THE NUMBER OF STUDENTS WHO REPORTED TO SOS-TELEAPEL SERVICE FOR HELP. (HTTP://WWW.SAVETNI.ORG/O_NAMA.HTML)

The Figure 1 shows a number of clients - the students of Niš University who reported to SOS-teleapel service of the Counseling 
Center. One should bear in mind that the graph only shows the data on the total number of clients annually, who reported for the use of this service, and not on the total number of reporting and the majority of clients reported more than once. Moreover, it is important to note that the Counseling Center is active 9 months a year (it doesn't work in July, August and January).

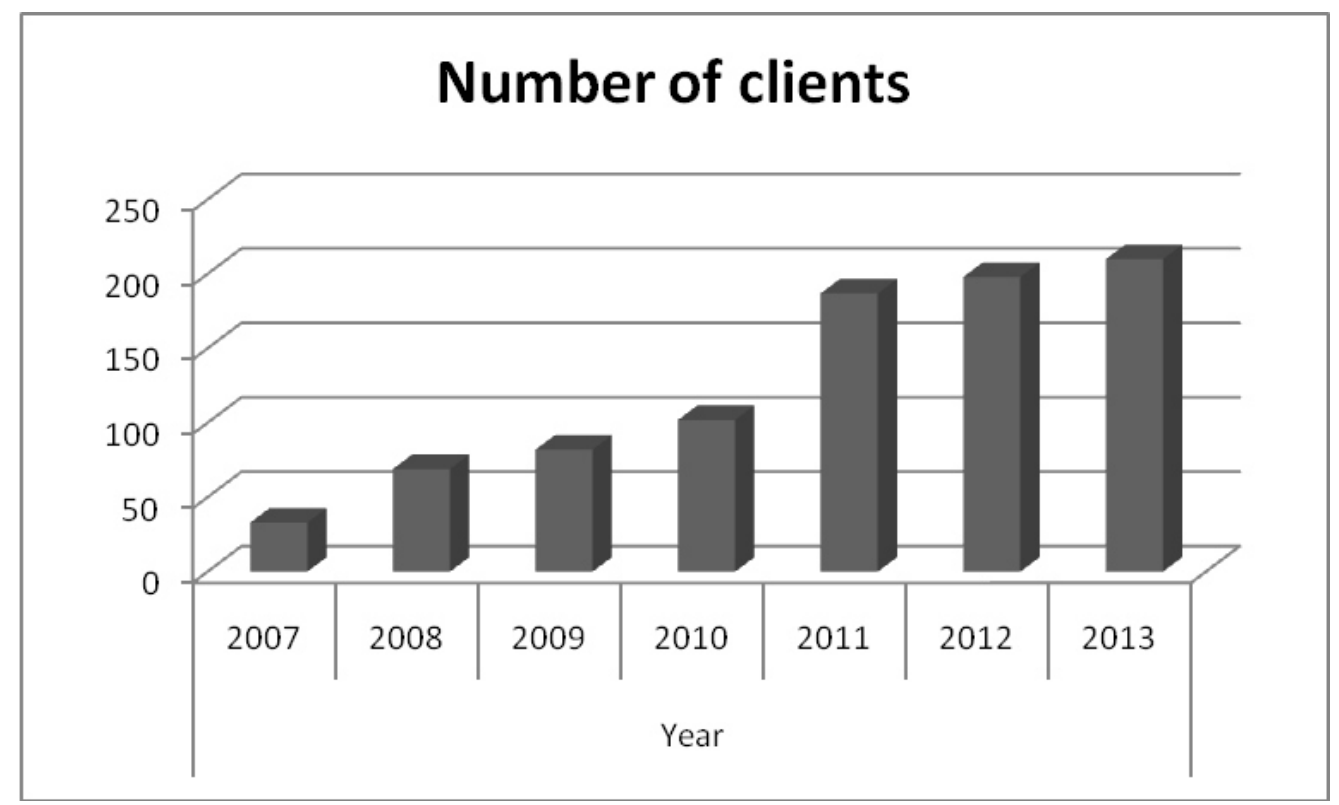

СЛИКA FIG. 2. THE NUMBER OF CLIENTS WHO REPORTED FOR HELP THROUGH DIRECT COUNSELING. (HTTP://WWW.SAVETNI.ORG/O_NAMA.HTML)

Figure 2 shows the number of the respondents who reported for the services of direct counseling. This information should be viewed in the light of the fact that from 2007 to 2010 the services of direct counseling were provided only by prof. dr Bojana Dimitrijević, a medical psychology specialist and a professor of clinical psychology at the Faculty of Philosophy, Niš University. In 2011, four more therapists (therapists under supervision) were engaged, and they started to provide the service of direct counseling, so the large increase in the number of clients in 2011 was expected.

Figure 3 shows a total number of internet counseling service users annually. It should be noted that this service has been available to students / potential users since November 2007. 


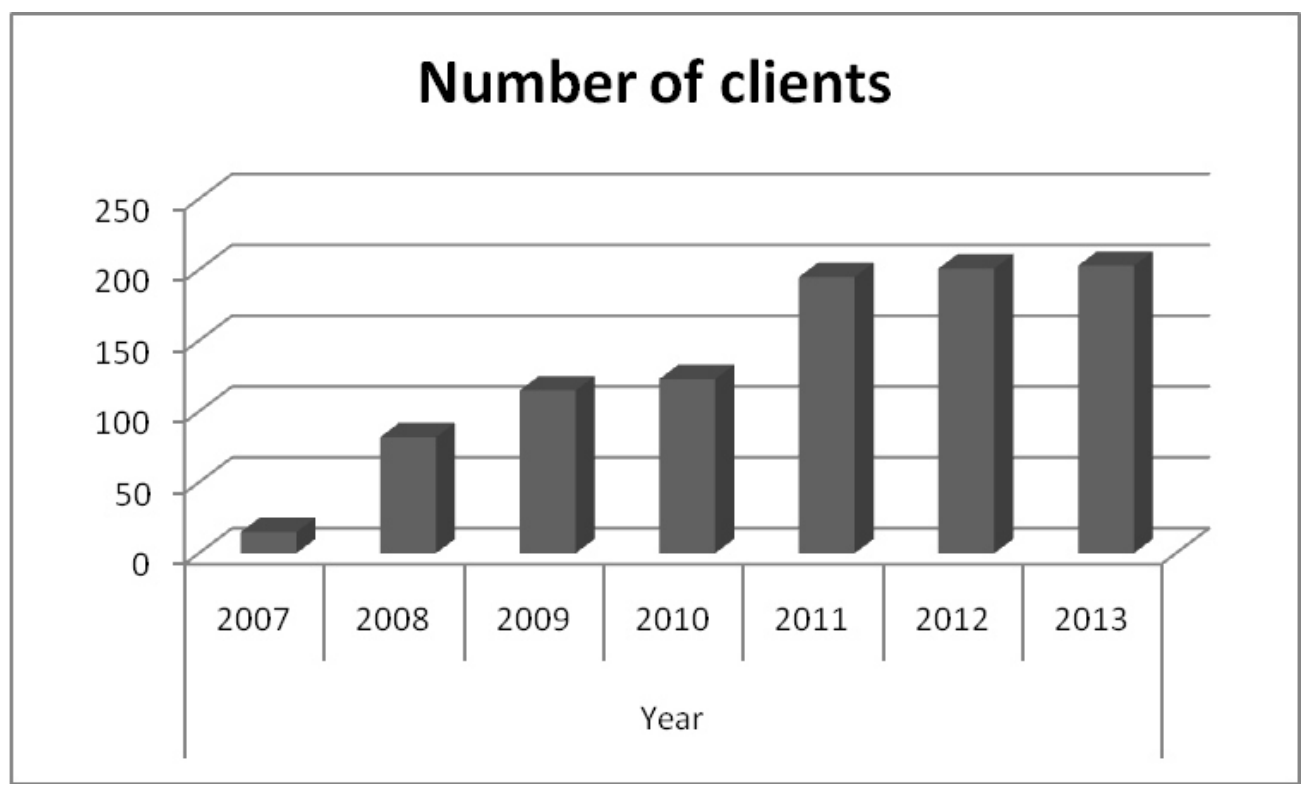

СЛИКA FIG. 3. THE NUMBER OF CLIENTS WHO REPORTED FOR HELP VIA INTERNET COUNSELING. (HTTP://WWW.SAVETNI.ORG/O_NAMA.HTML)

III) THE REVIEW OF THE MOST IMPORTANT PSYCHOLOGICAL PROBLEMS FACED BY THE USERS OF THE DIRECT COUNSELING SERVICES OF THE Psychological Counseling CENTER For STUdents

In addition to empirical studies conducted on a sample of students that could be potential users of the Psychological Counseling Center services, a research was conducted based on the data received from the students who were current users of the direct counseling service from the beginning to the end of 2013. The total number of the direct counseling users during 2013. was 210, however, the complete data were collected for 105 students, so in this paper, only the results of the respondents with the complete data will be shown.

The largest number of the respondents has learned about the existence of the Psychological Counseling Center for Students through other clients (40.7\%), 29.6\% through posters and leaflets from the promo campaign, $26 \%$ has found out through media (internet, television or radio) and $3.7 \%$ has found out for the activities of the counseling center from their friends. 


\begin{tabular}{|c|c|}
\hline THE DESCRIPTION OF THE SAMPLE & Percentage \\
\hline $\begin{array}{l}\text { Gender } \\
\text { Male } \\
\text { Female }\end{array}$ & $\begin{array}{l}28.6 \% \\
71.4 \%\end{array}$ \\
\hline $\begin{array}{l}\text { Working status } \\
\text { An unemployed person } \\
\text { An employed person or a free-lancer }\end{array}$ & $\begin{array}{l}95.2 \% \\
4.8 \%\end{array}$ \\
\hline $\begin{array}{l}\text { Emotional status } \\
\text { Single } \\
\text { In a relationship } \\
\text { Married } \\
\text { Simultaneously in multiple parallel relationships }\end{array}$ & $\begin{array}{l}27 \% \\
67.8 \% \\
2.7 \% \\
2.5 \%\end{array}$ \\
\hline $\begin{array}{l}\text { The place of residence and study } \\
\text { The place of residence in the city where they study } \\
\text { The place of residence outside the city where they study }\end{array}$ & $\begin{array}{l}85.7 \% \\
14.3 \%\end{array}$ \\
\hline $\begin{array}{l}\text { Seeking help for } \\
\text { Seeking help for themselves personally } \\
\text { Seeking help for his/her partner } \\
\text { Seeking help for a family member }\end{array}$ & $\begin{array}{l}91.6 \% \\
5.3 \% \\
3.1 \%\end{array}$ \\
\hline
\end{tabular}

TABLE 1: DESCRIPTION OF THE SAMPLE OF THE CLIENTS WHO WERE USERS OF DIRECT COUNSELING SERVICE DURING 2013.

THE TYPE OF THE PROBLEM BECAUSE OF WHICH THE CLIENT REPORTS

PERCENTAge

Problems in functioning at the faculty

$31.4 \%$

Within this category:

Problems with learning

Problems with organizing work activities and responsibilities

$18.2 \%$

Discontent with the faculty choice

$12.1 \%$

Problems with concentration

$9.1 \%$

Problems in relations with the professors and colleagues

$9 \%$

Problems with adapting to new conditions

$6.2 \%$

TABLE 2: TYPES OF PROBLEMS BECAUSE OF WHICH THE CLIENTS REPORTED FOR HELP IN THE FORM OF THE DIRECT COUNSELING DURING 2013. 


\begin{tabular}{ll}
\hline Anxiety disorders & $25.3 \%$ \\
From that: & \\
Panic disorder & $48.6 \%$ \\
Agoraphobia & $32.7 \%$ \\
Social phobia & $12.4 \%$ \\
Generalized anxiety disorder & $5.1 \%$ \\
OCD & $1.2 \%$ \\
\hline Emotional and sexual problems & $18.2 \%$ \\
From that: & \\
Various problems in a relationship & $76.7 \%$ \\
Loneliness & $12.1 \%$ \\
Lack of sexual activity & $5.8 \%$ \\
Impotence/frigidity & $5.4 \%$ \\
\hline Depressed mood & $14.6 \%$ \\
From that: & \\
Loss of the loved one & $54.2 \%$ \\
Leaving the parental home to study & $21.5 \%$ \\
Breaking up a relationship & $18.4 \%$ \\
Other reasons & $5.9 \%$ \\
\hline Problems in family functioning & $7.6 \%$ \\
From that: & \\
Problems in communication and interaction with parents & $89.2 \%$ \\
Recurring arguments among the family members & $9.5 \%$ \\
The disease of parents & $1.3 \%$ \\
\hline Suffering some form of violence (sexual, physical) & $2.9 \%$ \\
\hline TAre 2 Typs & \\
\hline
\end{tabular}

TABLE 2: TYPES OF PROBLEMS BECAUSE OF WHICH THE CLIENTS REPORTED FOR HELP IN THE FORM OF THE DIRECT COUNSELING DURING 2013.

\section{DISCUSSION}

The time of adolescence is the period of significant changes and rapid getting mature. It is also the period of crisis, when an adolescent is, in the transition between the childhood and adulthood, faced with numerous physical and psychical changes. Vulnerability of young people, especially those ones who have decided to study, and in some way decided to, in addition to regular stressors, deal with stressors related to academic community almost on daily basis, is the subject of scientific interest of a number of psychologists who have studied the issue of mental health of young people. 
Exactly the specificity of life and work of this part of the population (students), as well as the characteristic stressful life circumstances which are associated with the period of studies have been discussed in the introduction of the paper (DeStefano et al., 2001; Wilson et al., 1997, Kitzrow, 2003; Ergene and Yildirim, 2004; Fairbrother and Warn 2003;Turner and Berry, 2000; Al-Qaisy 2011; Ghaderi and Salehi, 2011; Tahmassian and Moghadam, 2011)

The special emphasis has been put on the importance of paying attention to the psychological problems that students face and their timely treatment in order to protect and improve the mental health of the students, and to reduce the number of students who quit the studies. We highlighted the lack of commitment of not only the institutions, but also the individuals - practitioners to this aspect of the health of the young people on the territory of the Republic of Serbia and other countries in the region, too.

By analyzing the results of the previous work of the Psychological Counseling Center for Students, which, as a pilot project, has existed at University of Niš since 2007, the following conclusions can be formulated:

- There is a need for using the services of the free psychological center for students at Niš University. It is indicated by the objective (the results of various clinical and non-clinical test) and subjective parameters (the attitude of students), and by the official data on the number of clients who have reported for the services of the Counseling Center during the five-year period (the number has permanently increased over the years). It is notable that, despite the stigma, in our region still attached to reporting for psychological help, this way of providing free psychological help proved to be effective and acceptable to the population of students.

- The students of Niš University have expressed willingness for using the services of the free Psychological Counseling Center. There is a great interest of students for visiting seminars, forums, workshops covering the topics related to the prevention of mental disorders, and preservation of mental health of students.

- The most common problems because of which the students who have used the service of direct counseling have reported are related to the functioning at the faculty (problems with 
learning, organization of work activities and responsibilities, discontent with the faculty choice, problems with concentration, problems in the interpersonal sphere / relations with professors and colleagues /, problems with adapting to new conditions), but anxiety disorders are quite frequent, too (panic disorder, agoraphobia, social phobia, general anxiety disorder, OCD, and other). From the sociodemographic characteristics of the people who have reported for this kind of psychological help, the predominant are the females, the unemployed and the people who are in a relationship or marriage and who have permanent residence in Niš.

CONCLUSION The sensitivity of the period of adolescence, the impact of negative social, economic, and even psychological circumstantial factors (especially the impact of adverse life circumstances and stressful factors on the territory of the Republic of Serbia, but also in general in former Yugoslavia) on the young people who have opted for academic training, should be a sufficient alarm for psychologists, pedagogues, sociologists, and also for all relevant state and local authorities to seriously address the issue of mental health of this population.

The real consequences of traumatic factors in our region are now difficult to determine more precisely and their reverberations will be clearer by examining through longitudinal studies and observations, which will, unfortunately, only years and decades ahead, objectify in a significantly greater extent. We would say that neither in Serbia, nor in the countries in the region (Macedonia, Montenegro, Croatia, Bosnia and Herzegovina, Albania) there is enough attention to the different measures of primary, secondary, and even tertiary prevention of the mental health of the young. Experience of Western European countries in the work of psychological counseling centers for students located at the prestigious universities tell about the positive effects of timely treatment of the psychological problems of students. Implementation of the Psychological Counseling Center for Students at Niš University, even in the form of a pilot project, also proves to be very useful and to be a positive measure of the primary prevention of mental health. However, the authors think that institutionalization of the aforementioned project, with the possibility of creating the 
network of psychological counseling centers of this type in the country and region would bring broader effects and contribute to the more comprehensive work on the prevention and improvement of mental health of students. It can only be assumed that the situation is similar in the most countries in the region (Bosnia and Herzegovina, Croatia, Serbia, Macedonia, Montenegro, Bulgaria, etc.). In any case, it is possible to implement the similar research (similar to methodology and parameters) in some other countries and make comparisons. Nigerian university students. Prevalence and sociodemographic correlates. Social Psychiatry and Psychiatric Epidemiology, 41: 674-678

Arnett, J. J. (2000) Emerging adulthood: A theory of development from the late teens through the twenties. American Psychologist, 55, 469-480.

Al-Qaisy, L. (2011): The relation of depression and anxiety in academic achievement among group of university students. International Journal of Psychology and Counseling, 3 (5), 96-100.

Benton, S. A., Robertson, J. M., Tseng, W-C, Newton, F. B. and Benton, S. L. (2003): Changes in Counseling Center Client Problems Across 13 Years. Professional Psychology: Research and Practice, 34 (1), 66-72.

Biro, M. (2001): Diagnostic Assessment of Personality. MMPI-202. Belgrade: Center for Applied Psychology

DeStefano, T. J., Mellot, N. R. and Petersen, D. J. (2001): A Preliminary Assessment of the Impact of Counseling on Student Adjustment to College. Journal of College Counseling, 4 (2), 113-121.

Dimitrijević, B. and Ranđelović, D. (2012): Aggressiveness and Susceptibility to Stress in Serbian Students from University of Nis and University of Pristina-Kosovska Mitrovica. Svit socialınih komunikaciŭ, volume 7, pp. 97104.

Eisenberg, D., Gollust, S. E., Golberstein, E. and Hefner, J. L. (2007): Prevalence and Correlates of Depression, Anxiety, and Suicidality among University Students. American Journal of Orthopsychiatry, 77 (4), 534-542.

Ergene, T., Yildirim, I. (2004). Depression among university entrance examination candidates. The Journal of Psychiatry, Psychology and Psychopharmacology, 12, 91-100.

Fairbrother, K., Warn, J. (2003). Workplace Dimensions, Stress and Job Satisfaction, Journal of Managerial Psychology, 18(1): 8-21.

Furr, S. R., Westefeld, J. S., McConnell, G. N., \& Jenkins, J. M. (2001). Suicide and depression among college students: A decade later. Professional Psychology: Research and Practice, 32, 97-100. 
Gallagher, R. P. (2011): National Survey of Counseling Center Directors 2011. The International Association of Counseling Services, Inc.

Ghaderi, A. R. and Salehi, M. (2011): A Study of the Level of Self-Efficacy, Depression and Anxiety between Accounting and Management Students: Iranian Evidence. World Applied Sciences Journal, 12 (8), 1299-1306.

Hodges, S. (2001): University Counseling Centers at the Twenty-First Century: Looking Forward, Looking Back. Journal of College Counseling, 4, 161173.

Kitzrow, M. A. (2003): The Mental Health Needs of Today's College Students: Challenges and Recommendations. NASPA Journal, 41(1), 165-179.

Mitrovic, M., Hadži Pešić, M., Mitić, P. (2013). Strategies of Facing Stress Situation and Students' Subjective Feelings of Welfare. Journal of Education, LXII, No.2, pp. 318-330.

Nerdrum P, Rustøen T, Rønnestad MH (2006). Student psychological distress: A psychometric study of 1750 Norwegian, 1st-year undergraduate students. Scandinavian Journal of Educational Research, 50(1): 95-109.

Ovuga E, Boardman J, Wasserman D (2006). Undergraduate student mental health at Makerere University, Uganda. World Psychiatry, 5(1): 51-52.

Sokol, J. T. (2009): Counseling Psychology within the University: A Study of Roles and Functions. Graduate Journal of Counseling Psychology, 1 (2), 121-129.

Tahmassian, K. and Moghadam N. J. (2011): Relationship between SelfEfficacy and Symptoms of Anxiety, Depression, Worry and Social Avoidance in a Normal Sample of Students. Iranian Journal of Psychiatry and Behavioral Science, 5 (2), 91-98.

Turner, A. L., Berry, T. R. (2000). Counseling center contributions to student retention and graduation: A longitudinal assessment. Journal of College Student Development, 41(6), 627-636.

Voelker R (2003). Mounting student depression taxing campus mental health services. Journal of the American Medical Association /JAMA, 289: 2055-2056.

Wardle, J., Steptoe, A., Guliš, G., Sartory, G., Sek, H., Todorova, I., Vogele, C. and Ziarko, M. (2004): Depression, Perceived Control, and Life Satisfaction in University Students from Central-Eastern and Western Europe. International Journal of Behavioral Medicine, 11 (1), 27-36.

Wilson, S., Mason, T., \& Ewing, M. (1997). Evaluating the impact of receiving university-based counseling services on student retention. Journal of Counseling Psychology, 44(3), 316-320.

Yildirim, I. (2006). Daily hassles and social support as predictors of academic achievement. Hacettepe University Journal of Education, 30, 258-267.

Zubić, I., Dimitrijević, B., Todorović, D. (2012). Psychopathological Manifestations among the Students of Different Faculties of Niš University, 
Psychological Development, Mental Health and Work - Thematic Collection of Papers, Faculty of Philosophy in Niš, 227-235.

http://www.savetni.org/o_nama.html. visited on: 07/12/2014 https://www.nottingham.ac.uk/counselling/counselling/index.aspx. Visited on: 07/12/2012 
ДУШАН Ј. РАНЪЕЛОВИЋ

УНИВЕРЗИТЕТ У ПРИШТИНИ СА ПРИВРЕМЕНИМ СЕДИШТЕМ

У КОСОВСКОЈ МИТРОВИЦИ, ФИЛОЗОФСКИ ФАКУЛТЕТ

МилИцА 3. МИТРовић

УНИВЕРЗИТЕТ У НИШУ

ФИЛОЗОФСКИ ФАКУЛТЕТ

ДУШАН Љ. ТОДОРОВИЋ

УНИВЕРЗИТЕТ У НИШУ

ФИЛОЗОФСКИ ФАКУЛТЕТ

Период студирања је време актуализације капацитета појединца у скоро свим аспектима живота. Студенти се суочавају са променама повезаним са развојним периодом кроз који пролазе, на које се надовезују нови адаптивни захтеви током професионалног оспособљавања. Повишење стопе психолошких проблема упућују на неопходност постојања студентских служби за пружање психолошке помоћи. Резултати истраживања указују на позитивне ефекте саветовања и на значај универзитетских саветовалишта за студентску популацију, утицај на њихов академски успех, субјективно благостање и останак на факултету. Државне институције, као и установе задужене за праћење и очување здравља младих као да не чине довољно на пољу превенције, поготову превенције у области менталног здравља. Чињеница је да у нашој земљи постоји недостатак различитих форми ванинституционалних облика пружања психолошке подршке младима, поготову не оних који би ठили доступни и финансијски приуштиви. Пилот пројекат „Психолошко саветовалиште за студенте" на Универзитету у Нишу је један од највећих и најтрајнијих пројеката ове врсте на универзитетима у региону. Услуге саветовалишта су потпуно ठесплатне, а реализују се преко три сектора: Саветовање, Едукације и Истраживачки сектор. У раду су презентовани квантитативни резултати рада Психошлоког Саветовалишта за студенте у периоду од 2007 - 2013 године. Резултати су сагледани преко три параметара: 1) Резултати најзначајнијих емпиријских истраживања менталног здравља студената у поменутом периоду; 2) Дескриптивни подаци о броју клијената који су користили услуге психолошког Саветовалишта; 3) Приказ назначајнијих психолошких пробле- 
ма са којима се суочавају корисници услуга Психолошког саветовалишта за студенте.

Извештаји о раду Саветовалишта показују да су студенти задовољни услугама саветовалишта, да постоји потреба за таквом врстом психолошких услуга (субјективни и објективни аспоекти), као и велико интересовање студената за похађање семинара и трибина на којима ठи се разматрали различити аспекти менталног здравља. Имплементација Психолошког саветовалишта за студенте, макар у форми Пилот пројекта, показала се као јако корисна мера примарне превенције у области менталног здравља. Сходно томе, институционализовање поменутог пројекта, уз евентуално ширење мреже психолошких саветовалишта оваквог типа на регионалном нивоу дало би шире ефекте и допринело свеобухватнијем раду на заштити и унапређивању менталног здравља студената у србији, али и у земљама окружења.

КљУчНЕ РЕчИ: студенти, психолошко саветовање, превенција. 